\title{
Students' Basic Movement Skills in Physical Education during the Online Learning
}

\author{
S Safruddin \\ Primary School Teacher Education \\ Study Program \\ University of Mataram \\ Mataram, Indonesia \\ safruddin@unram.ac.id
}

\author{
$\mathrm{N}$ Nasaruddin \\ Primary School Teacher Education \\ Study Program \\ University of Mataram \\ Mataram, Indonesia \\ nasaruddin@unram.ac.id
}

\author{
Arif Widodo* \\ Primary School Teacher Education \\ Study Program \\ University of Mataram \\ Mataram, Indonesia \\ arifwidodo@unram.ac.id
}

Muhammad Sobri

Primary School Teacher Education Study Program

University of Mataram

Mataram, Indonesia

muhammadsobri@unram.ac.id

\author{
R Radiusman \\ Primary School Teacher Education Study Program \\ University of Mataram \\ Mataram, Indonesia \\ radiusman@unram.ac.id
}

\begin{abstract}
Basic movement skills are one of the most important aspects of physical education. During online learning, students often make the less physical movement. This study aims to determine the basic locomotor movement skills, non-locomotor movement, and students' manipulative movement during online learning. This research used descriptive quantitative research. Data collection was carried out using a survey. The populations in this study were students of the Elementary Teacher Education Program at University of Mataram. The sample used in this research was the purposive proportional random sampling technique. The number of selected samples was 30 students. The instrument used in this study was a performance test instrument. Data collection used a descriptive measurement technique of tendency central size which includes the mean and median. Thus, the results showed that the students' locomotor movement skills were in the very poor category, the non-locomotor motion was not good and the manipulative movement was in a good category.
\end{abstract}

Keywords-locomotor movement, non-locomotor movement, manipulative movement, Elementary Teacher Education Program students.

\section{INTRODUCTION}

Basic movement skills are closely related to the physical ability of students. Basic movement skills are needed for every individual to support their daily activities, especially sports [1]. A student must master basic movement skills to facilitate various activities [2]. The ability to move is a basic technique in sports. Basic motion involves physical human activities [3]. The role of exercise for health is very important especially for children who are still growing [4]. Basic movement skills are divided into three parts of movement skills, which are locomotor motion, nonlocomotor motion and manipulative motion [5]. Basic movement skills are obtained from learning at the elementary school level which is very useful for the secondary school learning level until institutions learning.

Lately, the students' movement activities have decreased. One of the reasons is the implementation of online learning. The change from offline to online learning made various new problems, one of which is the change in learning behavior.
With online learning, most student learning activities are carried out online. Moreover, the large number of lecture assignments makes students spend more time in front of the laptop [6]. This problem caused fewer students movement activities. The reduced movement activities also have negative implications for the student's health. Based on the description that has been conveyed, it is necessary to survey the basic locomotor, non-locomotor, and manipulative movement skills for students.

There are several studies related to students' locomotor, non-locomotor, and manipulative basic movement skills. The first study discusses the suitability of locomotor and manipulative movements in early childhood [7]. The result of this study indicates that the locomotor and manipulative basic movement skills of early childhood showed quite good results. The second study examines the use of game models to improve the basic motor skills at the age of elementary school children [8]. The results showed that the game model can be used to improve students' locomotor, non-locomotor, and manipulative ability to move. The third research still uses a game model. The game used is a smart mine game. The results of this study showed that smart mine play can be used to improve the locomotor agility of early childhood [9]. The fourth research examines students' manipulative motor skills [10]. The results of this study stated that the students' manipulative ability was included in the moderate category.

\section{METHODS}

The type of research used is survey research. Survey research is a form of the planned collection with aim of explaining or studying social phenomena by analyzing the relationship between certain variables [11]. The research approach used was the descriptive approach. Descriptive research aims to describe the characteristics of several existing phenomena, either group or individual phenomena that are natural or human engineering with correct interpretations [12]. However, in this study, there was the treatment of the research subject. The populations in this study were the students of the Elementary Teacher Education Program at University of Mataram. Sampling in this study 
used the purposive proportional random sampling technique. The sampling technique uses certain considerations or goals based on the students' characteristics [13]. The instrument used in this study was a test instrument. The tests used to obtain data on basic non-locomotor movement skills are in the form of tests: (1) standing stork, to measure balance, (2) sit and reach, to measure flexibility. The locomotor basic movement skill test is in the form of tests: (1) standing long jump, to measure the explosive power of the leg muscles, (2) shuttle run, to measure agility, (3) to run 20 meters, to measure speed. The manipulative basic motion tests used are (1) throwing and catching a ball using one hand, and (2) throwing a ball using two hands which aims to measure the coordination between the eyes and hands. Data collection used was measurement techniques through tests [14]. The form of the test used is the locomotor, non-locomotor, and manipulative basic movement skills test. The data analysis technique used is a descriptive statistical analysis technique, the size of tendency central, which includes the mean, median, and mode.

\section{RESUlT AND DisCUSSIONS}

This study examines the basic locomotor, non-locomotor, and manipulative movement skills of students during online learning. The study began with making preparations including the research instruments and equipment needed during the research. Furthermore, the students measured basic movement skills was done. On the first day, measurements of locomotor ability were measured, the second day was non-locomotor motion measurements, and the third-day manipulative motion measurements.

\section{Locomotor movement}

The measurement results of locomotor movement after tabulation and data analysis can be seen as follows.

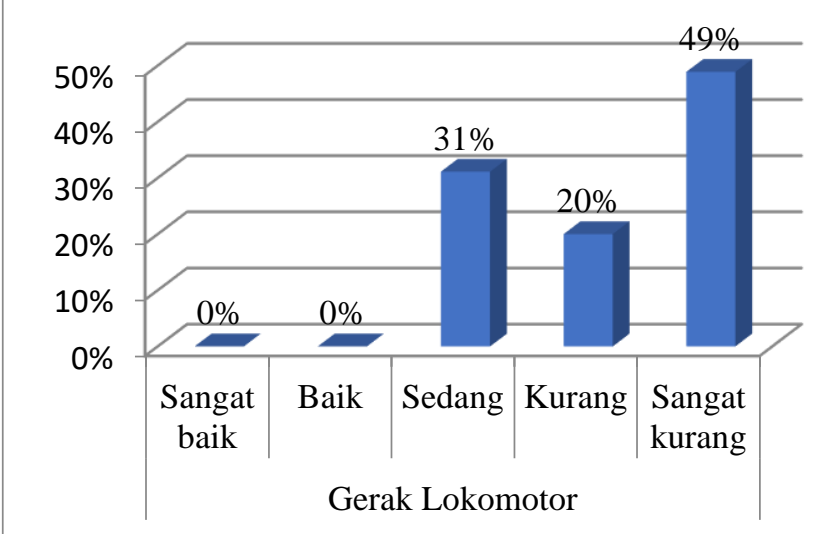

Fig. 1. Students' locomotor movement skills

Based on Figure 1, it can be seen that most students have very poor basic locomotor movement skills, reaching $49 \%$ of the 30 samples tested. Students who have poor abilities as much as $20 \%$ and $31 \%$ have sufficient abilities, while those who are included in the good and very good categories are $0 \%$ respectively.

\section{Non-Locomotor movement}

On the second day, non-locomotor skills were measured. The non-locomotor movement being tested is a standing stork to measure balance, and sit and reach to measure body flexibility. The results of measurements on non-locomotor motion can be seen as follows:

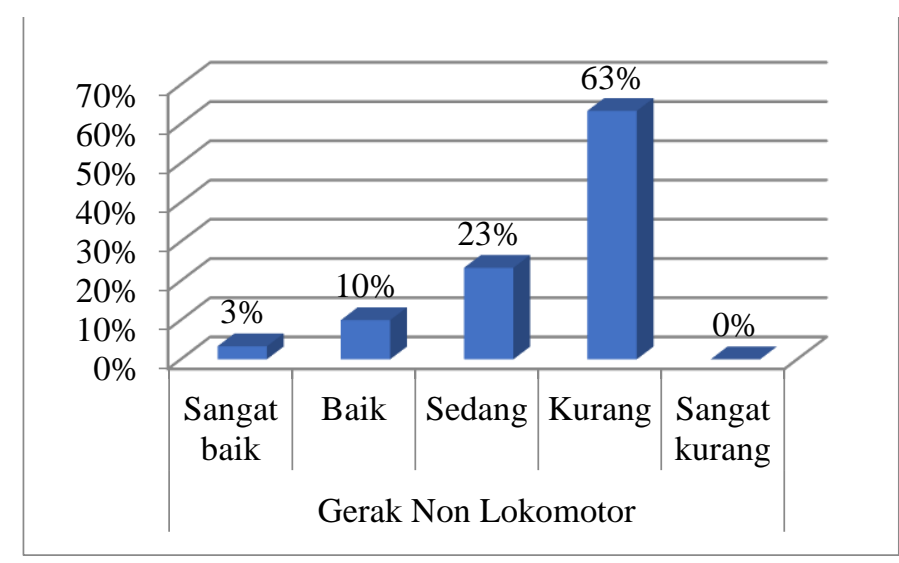

Fig. 2. Non-locomotor students' skills

Based on Figure 2, it can be seen that most students have a poor category on non-locomotor movement skills, which was $63 \%$ of the total research sample. The number of students who have a fairly good ability is $23 \%, 10 \%$ good ability, and $3 \%$ excellent ability. In measuring the nonlocomotor aspects of movement, there are no students with very poor abilities.

\section{Manipulative movement}

On the third day, the manipulative movement skills were assessed. The basic manipulative motion tests used were throwing and catching the ball using one hand, and throwing the ball using two hands which aims to measure the coordination between the eyes and hands. The results of manipulative motion measurement are presented as follows:

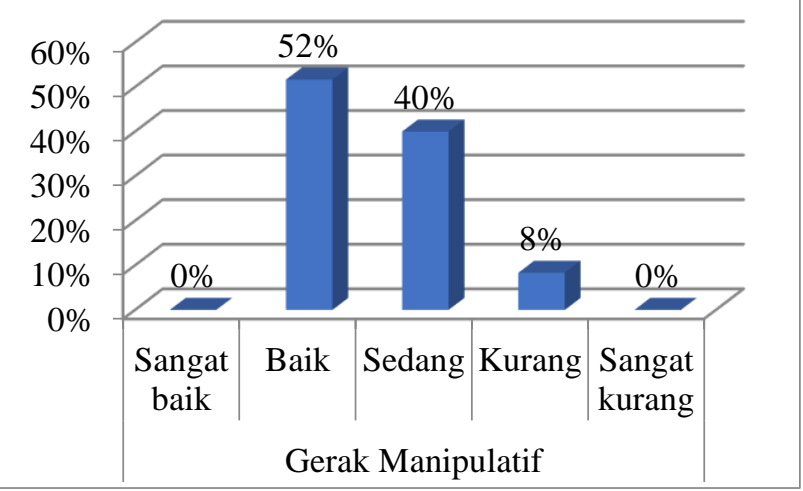

Fig. 3. Students' manipulative movement skills

Based on Figure 3, it can be seen that most students have good manipulative movement skills where the number reaches $52 \%$ of the total sample. In the second place, there are students with quite good categories, amounting to $40 \%$. Furthermore, in the third category, which included in the less category there is only $8 \%$. In measuring manipulative movement skills, there were no students in the very good or very poor category. 
Based on the performing tests that have been carried out, there are different data percentages on each basic motion indicator. Students get the worst results on the locomotor aspect of the movement. One of the reasons is that during online learning, students' physical movements reduced a lot, especially activities in moving places. It could be understood considering that locomotor motion is the movement of moving the body [8]. Locomotor movement requires greater flexibility and power. In non-locomotor motion, students get better results when compared to locomotor motion. The reason is that non-locomotor movements can still be done during online learning because the body does not need to move places. The best results are obtained with manipulative motion. Manipulative movements use tools so that they are easier to do [7]. However, in general, students' basic movement skills can be in the poor category. This indicates that there are problems in the students' physical health [4].

Spending more time in front of the laptop can have various adverse effects on an individual's health. Many students faced stress due to online learning [15]. Not only is it stressful, online learning also interferes with eye health and hinders the movement of body muscles. Moreover, the nonoptimal physical education during online learning makes student movement skills reduced. This is evidenced by the students' less basic motor skills during this research. This kind of condition needs attention due to the physical education that is not only to develop the physical realm, but also to develop aspects of health, physical fitness, skills, critical thinking, emotional stability, social skills, and moral action through physical activities and sports [16]. This is the following opinion which states that physical education is an educational process that utilizes physical activity to produce holistic changes in individual quality, both physically, mentally, and emotionally [17]. From some of the opinions above, it concluded that physical education is very important to implement because learning physical education does not only involve psychomotor aspects but also involves cognitive and affective aspects that are taught to a person. In the physical education learning process, teachers are expected to teach various basic movement skills, game/sports techniques, and strategies also the internalization of character values.

Sports are identical to the values of sportsmanship, honesty, cooperation, and mutual respect. The value of mutual respect must always be instilled in every lesson so that student behavior reflects good character [18]. This is following the opinion [19] which states that one of the goals of physical education is to lay a strong moral character foundation, build a strong personality foundation, peaceloving attitude, social attitudes, and tolerance in the context of cultural, ethnic, and religious progress. Based on this opinion, it can be concluded that the purpose of physical education is to develop skills in maintaining the safety of oneself and others, knowing and understanding the concept of physical activities and sports as information to achieve health, fitness, and healthy lifestyles, and being able to fill spare time with physical activities.

The benefit of physical exercise is as a means of maintaining physical fitness [20]. Also, exercise is also beneficial for promoting good physical growth and mental development. One of the most important elements of sport is basic mobility [21]. Through sports activities, basic movement skills can be improved. However, sports activities are not always a priority for most people. This is evidenced by the low basic movement skills possessed by students. Based on the results of a survey conducted on students of the Elementary Teacher Education Program at University of Mataram, it can be seen that the students' basic motor skills are still low. From the three indicators tested, the only manipulative motion was in a good category, while the aspect of locomotor and non-locomotor motion was in the very poor and unfavorable categories. This indicates that students have not been doing sports regularly.

One of the reasons for the low basic movement skills is the low motivation to exercise. Moreover, the phenomena of cyber addict activities make students lazy to do physical activities [22]. It cannot be denied that online learning activities have many negative impacts [23]. Students' unpreparedness in adjusting to online learning has various negative impacts [24]. Therefore, a campaign is needed to carry out sports activities for students. Doing physical activities and exercising regularly can achieve perfect physical growth, a healthy lifestyle and fitness, and a positive attitude. This is because in addition to improve movement skills and physical fitness, sports can also establish good attitudes and behavior for individuals and groups.

Through physical education learning, the student can channel body movements. Moreover, mobility can also shape, foster, and develop the potential of students. Learning sports is an important part of the education and learning process because it is characterized by motor elements that have a major contribution to developed the students' potential to the maximum. Sport is a form of motion learning that is explored through various physical activities. Moving learning is very important to explore and master [25]. Therefore, the solution must be found due to the low basic of students' movement skills. It is necessary to make serious efforts and cooperation so that the mission of educational organizations can achieve. [26]. Due to the low motivation of students' basic mobility in exercising, it is necessary to have the right approach and policies so that students are motivated to do some basic exercise every day.

\section{CONCLUSSION}

Based on the results study, it can be concluded that the students' basic movement skills during online learning are not satisfactory. Students are facing a reduction in basic movement skills, both in locomotor, non-locomotor, and manipulative movement. The low students' movement is due to the online learning activities and less physical activity. It is necessary to carry out policies and interventions from policyholders so the students of the Elementary Teacher Education Program movement skills can increase

\section{REFERENCES}

[1] A. Sobarna, S. Hambali, R. M. Rizal, and L. Sevtiadzi, "Hasil Keterampilan Lompat Jangkit," J. Pendidik. Olahraga, vol. 8, no. 1, p. 53, 2019.

[2] Y. I. Utari and N. Indahwati, "Upaya meningkatkan gerakan dasar lokomotor anak tungrahita," J. Pendidik. Olahraga dan Kesehat., vol. 3, no. 2, pp. 279-282, 2015.

[3] D. Sabatini, "Faktor-Faktor Yang Mempengaruhi Kecepatan, Kekuatan, Dan Daya Ledak Terhadap Tendangan Pada Atlet 
Taekwondo," J. Pendidik. Olahraga, vol. 8, no. 2, pp. 85-95, 2019.

[4] B. S. Pane, "Peranan Olahraga Dalam Meningkatkan Kesehatan," J. Pengabdi. Kpd. Masy., vol. 21, no. 79, pp. 1-4, 2015.

[5] R. M. Pertiwi, N. Nurhasan, and T. A. R. Syam, "Pengembangan Model Pembelajaran Sirkuit Untuk Membantu Pola Gerak Lokomotor, Non Lokomotor, dan Manipulatif Anak Down Syndrome," Jendela Olahraga, vol. 3, no. 2, pp. 26-36, 2018.

[6] A. Widodo, I. Ermiana, and M. Erfan, "Emergency Online Learning: How Are Students 'Perceptions?," in 4th Sriwijaya University Learning and Education International Conference (SULE-IC 2020), 2020, vol. 513, pp. 263-268.

[7] one welly rahajeng, "Kesesuaian Keterampilan Gerak Lokomotor Dan Manipulatif Anak Usia 4-5 Tahun Segugus Ii Kecamatan Galur," J. Pendidik. Anak Usia Dini Ed., vol. 2, no. 5, pp. 171-181, 2016.

[8] A. Hidayat, "Peningkatan Aktivitas Gerak Lokomotor, Nonlokomotor Dan Manipulatif Menggunakan Model Permainan Pada Siswa Sekolah Dasar,” J. Pendidik. Jasm. Dan Olahraga, vol. 2, no. 2, pp. 21-29, Sep. 2017.

[9] D. F. Rahayu and I. Khsanah, "Upaya Meningatkan Ketangkasan Gerak Lokomotor Anak Melalui Permainan Ranjau Pintar Pada Kelompok A TK An Nur Kaliwungu Kendal Tahun Ajaran 2012/2013," Paudia J. Penelit. Dalam Bid. Pendidik. Anak Usia Dini, vol. 2, no. 2, pp. 73-83, Sep. 2017.

[10] A. Komari, "Kemampuan Gerak Manipulatif Mahasiswa Peserta Perkuliahan Permainan Net Tahun Angkatan 2010," J. Pendidik. Jasm. Indones., vol. 10, no. 1, pp. 8-14, 2014.

[11] R. A. Maolani and U. Cahyana, Metodologi Penelitian Pendidikan. Jakarta: PT Rajagrafindo Persada., 2015.

[12] N. Nazir, Metode Penelitian. Bogor: Ghalia Indonesia, 2014.

[13] Sugiyono, Metode penelitian pendidikan pendekatan kuantitatif kualitatif, dan R\&D. Bandung: Alfabeta, 2013.

[14] T. Baumgartner and L. . Hensley, Conducting and Reading Research in Healt and Human Performance, 4th ed. Santiago: McGraw Hill Companies, 2006

[15] A. Widodo and Nursaptini, "Problematika Pembelajaran Daring dalam Perspektif Mahasiswa," Elem. Sch. Educ. J., vol. 4, no. 2, pp. $100-115,2020$.
[16] E. Sudirjo and M. U. Alif, Pertumbuhan dan Perkembangan Motorik. Sumedang: Upi Sumedang Press, 2018.

[17] A. Prastowo, Analisis Pembelajaran Tematik Terpadu. Jakarta: Prenandamedia, 2019.

[18] A. Widodo, M. A. Maulyda, A. Fauzi, D. Sutisna, N. Nursaptini, and U. Umar, "Tolerance Education Among Religious Community Based on the Local Wisdom Values in Primary Schools," in Proceedings of the 1st Annual Conference on Education and Social Sciences (ACCESS 2019), 2020, vol. 465, no. Access 2019, pp. $327-$ 330 .

[19] T. Subroto, Strategi Pembelajaran Penjas. Jakarta: Universitas Terbuka, 2008

[20] E. Susanto, "Manfaat Olahraga Renang Bagi Lanjut Usia," MEDIKORA, vol. 6, no. 1, pp. 53-64, Jun. 2015.

[21] Maryani and Husdarta, Menejemen Pendidikan Jasmani, 1st ed. Bandung: Alfabeta, 2011.

[22] A. Widodo et al., "Upaya Pelestarian Permainan Tradisional melalui Kegiatan Kemah Bakti Masyarakat," ETHOS J. Penelit. dan Pengabdi. Kpd. Masy., vol. 8, no. 2, pp. 257-264, Jun. 2020.

[23] D. Sutisna, A. Widodo, N. Nursaptini, U. Umar, M. Sobri, and D. Indraswati, "An Analysis of the Use of Smartphone in Students' Interaction at Senior High School," in Proceedings of the 1st Annual Conference on Education and Social Sciences (ACCESS 2019), 2020, vol. 465, no. Access 2019, pp. 221-224.

[24] A. Widodo, N. Nursaptini, S. Novitasari, D. Sutisna, and U. Umar, "From face-to-face learning to web base learning: How are student readiness?," Prem. Educ. J. Pendidik. Dasar dan Pembelajaran, vol. 10, no. 2, pp. 149-160, Dec. 2020.

[25] H. Rahyubi, Teori-Teori Belajar dan Aplikasi Pembelajaran Motorik. Bandung: Nusa Media Ujungberung, 2014.

[26] N. Nursaptini, A. P. Anar, D. Indraswati, A. Wiododo, S. Novitasari, and D. Sutisna, "School Operational Assistance and Challenges of Communities' Participation at Madrasah Tsanawiyah in Central Lombok," in Proceedings of the 1st Annual Conference on Education and Social Sciences (ACCESS 2019), 2020, vol. 465, no. Access 2019, pp. 279-282. 